\title{
КЛИНИЧЕСКИЙ СЛУЧАЙ БОЛЕЗНИ ГИРКЕ У РЕБЕНКА РАННЕГО ВОЗРАСТА
}

\author{
Филимонова М.И. ${ }^{1}$, Зарипова Ю.Р. ${ }^{2}$, Варламова Т.В., \\ ${ }^{1}$ ГБУЗ РК «Детская республиканская больница», Петрозаводск \\ ${ }^{2}$ ФГБОУ ВО «Петрозаводский государственный университет»
}

Гликогеновая болезнь (ГБ, гликогенозы, болезни накопления гликогена, МКБ10 - Е 74.0) общее название группы наследственных заболеваний, связанных с нарушением углеводного обмена, а именно с метаболизмом гликогена, что приводит к нарушению его синтеза или распада и сопровождается избыточным накоплением этого полисахарида в основном в печени и/или мышцах. В зависимости от того или иного энзимного дефекта, а также от типа поражаемой ткани в настоящее время выделяют 15 типов ГБ. В мировой медицине ГБ известна уже в течение 97 лет. В России первое клиническое наблюдение пациента с этим заболеванием описано Полевицкой Н.К в 1946 г., а уже к началу 1970-х гг. сообщено о 20 случаях ГБ в нашей стране (Орехов К.В. и соавт.). По различным оценкам общая частота заболеваемости ГБ в мире составляет 1 случай на 20000-43000 живорожденных детей. В Российской Федерации до настоящего времени численность пациентов с гликогенозами не известна.

В зависимости от уровня поражения в ферментной системе глюкозо-6-фосфатазы выделяют 2 основных подтипа заболевания: Ia и Ib. Клинические симптомы всех подтипов гликогеновой болезни I типа практически идентичны. Описание основных симптомов этого типа гликогеноза и их причин может служить основанием для понимания симптомов всех остальных типов. Гликогеновая болезнь Іа типа (болезнь фон Гирке, гепаторенальный гликогеноз, гепатонефромегальный гликогеноз, дефицит глюкозо-6-фосфатазы). Гликогеноз типа Іа встречается примерно у 80\% пациентов среди всех больных гликогенозом I типа. Частота встречаемости гликогеновой болезни Іа типа в общей популяции составляет 1 к 100 000-300 000. Гликогеновая болезнь Іа типа — аутосомно-рецессивное заболевание, вызываемое дефицитом глюкозо6-фосфатазы и ассоциированное с избыточным накоплением гликогена нормальной структуры в печени, почках и слизистой оболочке кишечника. Клинический фенотип гетерогенен, различают две клинические формы гликогеновой болезни I типа. При первой форме течение заболевания острое. Возраст начала болезни - неонатальный период, чаще первый год жизни (3-4 мес). Начинается заболевание с проявлений гипогликемии и лактат-ацидоза, вскоре появляется выраженная гепатомегалия и/или гипогликемические судороги. Гепатомегалия обусловлена как накоплением гликогена (не только в цитоплазме, но и в ядрах клеток), так и накоплением липидов (стеатоз печени). Почки также увеличены и содержат депозиты гликогена в канальцевом эпителии, но селезенка остается нормальных размеров. Для болезни характерны большой, выступающий живот, отставание в росте, гипотрофия, перераспределение подкожной жировой клетчатки с локальными отложениями преимущественно на щеках, груди, ягодицах, бедрах, «кукольное» лицо. Могут возникать кожные ксантомы на локтях, коленях, ягодицах, бедрах наряду с дегенерацией сетчатки в виде множественных дискретных парамакулярных вкраплений желтого цвета. У некоторых больных описана интермиттирующая диарея неясного генеза. Гипогликемия, чаще бессимптомная или с судорогами, тяжелым лактат-ацидозом, возникает при малейшем голодании. При отсутствии свое временной верификации диагноза и должного лечения гипогликемия может привести к смерти больного в возрасте от одного года до 3 лет. Метаболический ацидоз ухудшает состояние больного и приводит к декомпенсации с развитием респираторного дистресс-синдрома при заболеваниях верхних дыхательных путей.

Клинический случай: ребенок А, 3 месяцев, поступил в Детскую Республиканскую больницу (г. Петрозаводск) с жалобами на увеличение размеров живота с рождения, периодическое беспокойство в последние 2 недели. 
Из анамнеза: ребенок от 2 беременности (1-я беременность - замершая) на фоне хронического гастрита, хронической герпетической инфекции, инфицированности цитомегаловирусом, вагинита в 18 недель, ОРВИ в 22 недели, стрептококкового тонзиллита в 23 недели. Роды 1-е, путем плановой операции кесарево сечение. Срок гестации - 40 недель. Оценка по шкале В. Апгар-9/9 баллов. Вес4050 г, длина- 55 см, окружность головы - 36см, окружность груди - 35см. При рождении состояние ребенка удовлетворительное. В раннем неонатальном периоде неоднократные эпизоды гипогликемии, купирующиеся инфузионной терапией. На 7-е сутки ребенок был переведен в республиканский неонатальный центр с диагнозом перинатальная инфекция. При поступлении - размеры печени $+2,5$ см из-под края реберной дуги. УЗИ брюшной полости - гепатоспленомегалия. диффузные изменения паренхимы печени, поджелудочной железы, увеличение размеров почек. В связи с гепатонефромегалией проведено обследование, по результатам которого данных за инфекционное поражение печени, почек не получено. На 14 сутки жизни - печень +4 см из-под края реберной дуги. Выписан из отделения в связи с клиникой ОРВИ в стабильном состоянии. Далее наблюдался амбулаторно педиатром. В 3 месяца - при профилактическом осмотре участковым педиатром отмечается увеличенный в объеме живот, гепатомегалия - печень выступает на 3-4 см из-под края реберной дуги. В клиническом анализе крови НВ 112 г/л, СОЭ 22 мм/ч. Выполнено УЗИ брюшной полости: правая доля печени - 97 мм, левая доля печени - 64 мм, на 8 см выступает из под края реберной дуги, воротная вена 5 мм, холедох не расширен, контуры печени четкие, ровные, эхогенность паренхимы диффузно повышена, желчные протоки не расширены, желчный пузырь сокращен. Поджелудочная железа: 7:4:7 мм контуры четкие, ровные, эхогенность паренхимы обычная. Селезенка: 61:24 мм, структура однородная. Надпочечники правильной формы, структура не изменена. Почки расположены на обычном уровне, контуры четкие, неровные, структура правильная, эхогенность паренхимы диффузно повышена, размеры правой почки 68:27мм, толщина паренхимы 710 мм, размеры левой почки 70:30 мм толщина паренхимы 9-12 мм. Заключение гепатоспленомегалия. Диффузные изменения паренхимы печени и почек. Направлен на консультацию к гематологу, гематологическая патология исключена, госпитализирован в ГБУЗ «ДРБ».

При поступлении в ГБУЗ «ДРБ» состояние ребенка средней тяжести. Самочувствие не нарушено. Температура тела на нормальных цифрах Правильного телосложения, удовлетворительного питания. Подкожно-жировая клетчатка распределена равномерно. Периферические лимфатические узлы не увеличены, при пальпации эластичные, не спаяны между собой и окружающими тканями. Кожные покровы, видимые слизистые розовые, чистые. ЧСС 120 в минуту, ЧД 44 в минуту. Обращает на себя внимание живот, увеличенный в размерах - окружность живота 51 см. Печень выступает на 11 см из-под края реберной дуги. Отмечается водянка оболочек правого яичка. Проведено обследование ребенка.

УЗИ брюшной полости - выраженная гепатомегалия (правая доля - 103мм, левая доля - 71мм, воротная вена 2 мм), нефромегалия, диффузные изменения паренхимы печени и почек.

Спиральная компьютерная томография: печень резко увеличена, занимает практически всю брюшную полость, смещая органокомплекс (максимальный вертикальный размер правой доли 147 мм, левой доли 108 см), билобарный размер на уровне ворот печени 165 мм, контур печени достаточно ровный. Плотность паренхимы резко снижена (в среднем около 15 ед. HU), накопление контрастного вещества неравномерное (в среднем +40 ед. HU). Внутри- и внепеченочные желчные протоки отчетливо не дифференцируются. Желчный пузырь сокращен, стенки утолщены. Селезёнка не увеличена, без видимых очаговых изменений. Участков патологического накопления контрастного вещества в паренхиме почек не выявлено. Выделительная функция почек сохранена. Надпочечники без видимых патологических изменений. Убедительных данных за увеличения лимфатических узлов на осмотренном уровне не получено. Заключение: КТ-картина диффузного поражения печени, гепатомегалия.

Сцинтиграфия: гепатомегалия, диффузные изменения в печени, селезенка 5,2:3,1см с некоторым повышением фиксации радиоизотопного препарата. 
Биопсия печени - выраженная жировая дистрофия.

ФГДС поверхностный дуоденит, дуодено-бульбарный рефлюкс, гипертонус привратника.

В анализах крови: анемия легкой степени тяжести, ускоренное СОЭ, L фетопротеин 93,26 ме/мл (норма 0-14,4), ГГТ 489,2 Ед/л, функциональные пробы печени нарушены, выраженная гипогликемия натощак, сменяющаяся повышением глюкозы после принятия пищи.

По данным анамнеза, клиники, лабораторно-инструментального обследования было заподозрено наследственное нарушение обмена веществ - гликогеноз. Проведено генетическое исследование крови в центральной генетической лаборатории г. Москва, подтвержден гликогеноз 1а типа (болезнь Гирке).

Таким образом, при тщательно изученном анамнезе, дебют заболевания произошел в раннем неонатальном периоде в виде персистирующей гипогликемии с присоединением позже гепатомегалии, нефромегалии и большого выступающего живота. Данные специфичные клинические проявления должны настораживать педиатра в плане диагностического поиска врожденных заболеваний обмена веществ с целью своевременной их диагностики и коррекции. 